\title{
SAINT UBALDESCA DI CALCINAIA
}

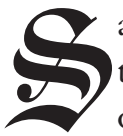
aint Ubaldesca was one of the earliest and most celebrated of the beati of the military-religious Order of Saint John of Jerusalem though, like most of the Hospital's saints, she was never formally canonized. ${ }^{1}$ The Order's saints were not military martyrs and some of the most distinguished, such as Saint Ubaldesca at Pisa and Saint Toscana at Verona, were not professed Hospitallers. ${ }^{2}$ An important exception was Saint Flor, who died in 1347; she was of noble birth, lived in an enclosed community of professed Hospitaller sisters and received a contemporary vita. ${ }^{3}$ Ubaldesca, who apparently died in 1205 or 1206 , was one of a group of saints whose lives and iconographies were deliberately fostered and elaborated for propaganda purposes by Giacomo Bosio and others from the late-sixteenth century onwards. ${ }^{4}$ For example, these saints were commemorated in fresco

1 The detailed standard study, discussing many aspects not covered here, is G. Zaccagnini, Ubaldesca, una santa laica nella Pisa dei secoli XII-XIII, Pisa 1995, which edits the varying Italian versions of her Vita. R. Amico, Il Monastero di S. Giovanni gerosolimitano in Pisa: Studio storico introduttivo. Inventario dell'Archivio e appendice di documenti, Pisa 2007, adds significant revisions, publishing important new archive materials from Pisa; she disputes some of Zaccagnini's findings but her work suffers from a lack of bibliographical and other information. The present study overlooks numerous errors throughout the standard literature which is listed by Zaccagnini.

2 A. Luttrell, H. Nicholson, Introduction: A Survey of Hospitaller Women in the Middle Ages, in: Hospitaller Women in the Middle Ages, ed. A. Luttrell, H. Nicholson, Aldershot 2006, pp. 17-18 and passim, here marginally revised.

3 P. L'Hermite-Leclercq, Fleur de Beaulieu (d. 1347), Saint of the Hospital of Saint John of Jerusalem, in: Hospitaller Women (as n. 2); B. Montagnes, Una Sainte quercynoise de l'Ordre de l'Hôpital: Saint Fleur, in: Les Ordres Réligieux Militaires dans le Midi de France (XII $-X I V^{e}$ siècle) (Cahiers de Fanjeaux 41), Toulouse 2006.

4 The best general study is L. Corti, Santi ed Eroe:l'Immaginario dei Cavalieri Gerosolimitani, in: Lungo il Tragitto crociato della vita, ed. L. Corti, Venice 2000. On Ubaldesca, add ibid., pp. 219-222, 248-253; Zaccagnini (as n. 1), pp. 149-163; Amico, pp. 15-18. See also H. Nicholson, Saints Venerated in the Military Orders, in: Selbstbild und Selbstverständnis der geistlichen Ritterorden, hrsg. v. R. Czaja, J. Sarnowsky (Ordines militares. Colloquia Torunen- 
by Mattia Preti in the Conventual church at Valletta in 1666, and in Ubaldesca's case some of her relics were sent from Pisa to Malta in 1586 while in 1626 a church was dedicated to her in the Maltese casale of Paula. ${ }^{5}$

A sermon, perhaps dating to the 1260's, by Federico Visconti, Archbishop of Pisa from 1254 to 1277 , spoke of a number of saintly Pisans, and particularly of Ubaldesca whom he described as a virgo and as patient in her sufferings. He himself had witnessed one of her posthumous miracles and he had evidence for numerous others in his curia, having apparently prepared a dossier for her intended canonization. ${ }^{6}$ The lost Latin original of Ubaldesca's Vita, which was possibly incomplete, may well have dated to the 1260 s. $^{7}$ Ubaldesca's existence is not in doubt, since it was confirmed to the archbishop by her contemporaries, but the circumstances of her life demand further discussion, especially in view of the fact that the original Latin Vita has not survived. A further miracle which was added to the Vita in or after 1409 was always difficult to understand. The initiative in the earliest exploitation of Ubaldesca's saintliness came at the time of her death from the Hospitaller Fr. Dotto degli Occhi who possibly acted as her confessor, while the intrigues leading to the extra miracle added in about 1409 involved another Hospitaller, Fr. Bartolomeo Palmieri da Cascina. ${ }^{8}$

Ubaldesca was a peasant girl from Calcinaia near Cascina some 14 kilometres south-east of Pisa who was born probably in about 1145. According to her Vita,

sia Historica XIII), Torun 2005; T. Licence, The Templars and the Hospitallers, Christ and the Saints, Crusades 4 (2005), pp. 39-57; T. Smith, Up in Arms: the Knights of Rhodes, the Cult of Relics, and the Chapel of St. John the Baptist in Siena Cathedral, in: Images, Relics, and Devotional Practices in Medieval and Renaissance Italy, ed. S. Cornelison, S. Montgomery, Tempe-Arizona 2005, pp. 213-238; M. Buhagiar, Essays on the Knights and Art and Architecture in Malta 1500-1798, Malta 2009, pp. 13-54.

5 This paper is not concerned with developments after 1206; the reliquary bust in San Sepolcro at Pisa (Zaccagnini (as n. 1), figs. 1-2) and the large statue in the Museo Nazionale at Pisa (Corti, (as n. 4), p. 220) are not now acceptable as medieval representations of Ubaldesca.

6 N. Bériou et al., Les Sermons et la Visite pastorale de Federico Visconti archevêque de Pise: 1253-1277, Rome 2001, pp. 249, 965-969; cf. Zaccagnini (as n. 1), pp. 18-22.

7 Bériou et al. (as n. 6), pp. 103, 105, dates the original to January 1268 at the earliest; Zaccagnini (as n. 1), p. 25, to 1262/1263. Amico (as n. 1), pp. 39-40, argues for the late-fifteenth or sixteenth century since various elements date from that period, but they might be additions to the original Latin or simply anachronistic changes.

8 A. Luttrell, Gli Ospedalieri a Siena dopo il 1312, in: La Chiesa di San Pietro alla Magione nel Terzo di Camollia a Siena: il Monumento - l'Arte - la Storia, ed. M. Ascheri, Siena 2001, pp. 111-113, 117-119 (reprinted in A. Luttrell, Studies on the Hospitallers after 1306: Rhodes and the West, Aldershot 2007, pp. 111-113, 117-119), studies Fr. Bartolomeo's career. 
her parents raised their only child to an honest life in which she helped in their domestic tasks. She occupied her spare time in penitence, prayer and charitable works for the poor until at the age of fourteen, possibly in about 1159 , she was baking bread when an angel appeared and instructed her to go to Pisa to the sisters of a monastery in the Carraia del Gonella in the Kinzica area just south of the river. Ubaldesca replied that she lacked the necessary virtue and that she would not be accepted without an entry payment, but the angel assured her that the sisters cared not for dowries but for virtue. After telling her parents who were working in the fields, she at once went to Pisa leaving the bread in the oven where it was found next morning miraculously unburnt. Ubaldesca's Vita described with some fantasy how she was received by the abbess of the Pisan house and the assembled populace, was conducted to the church by forty sisters and was dressed in the vesta monachale as a suora.

The Vita stated, probably incorrectly, that the monastery was already a Hospitaller house. The number of forty sisters is scarcely credible. Ubaldesca may well, however, have become some sort of donat or lay associate who did not take the full vows of religion or become a professed sister. In the thirteenth and fourteenth centuries the community, which had become a Hospitaller house, certainly included a number of associated donate, converse, commise and devote. ${ }^{10}$ Ubaldesca served the sisters and the sick with great humility, wore sackcloth, slept for only a few hours a day on a bed of boughs, and ate no more than bread and water every two or three days. On reaching adulthood she began a long life of public begging for the sisters. When badly wounded in the head by a falling stone she refused assistance. One day when several thirsty women asked her for water she passed them her bucket and the water in it changed to wine. ${ }^{11}$ She died aged about sixty, probably in 1205 or possibly in 1206; her feast was later celebrated on the day of the Holy Trinity. At some point before Ubaldesca's death the sisters' Pisan house, later dedicated to San Giovanni or San Giovannino, had become a monastery of the Hospitallers of Saint John in whose nearby church of San Sepolcro she was buried. ${ }^{12}$

The military-religious Order of Saint John grew out of a group of Benedictine hospices, one of them for women, which were founded in Jerusalem in the late-eleventh century. Very soon after the Latin conquest of the city in 1099 the main hospice passed into association with the Augustinian canons of the Holy Sepulchre, and in 1113 a papal privilege gave it a large measure of independence.

\footnotetext{
9 Vita in Zaccagnini (as n. 1), pp. 198-213.

10 Amico (as n. 1), pp. 22-29.

11 Vita in Zaccagnini (as n. 1), pp. 212-237.

12 Proposed chronology ibid., pp. 28-35.
} 
The privilege also confirmed the Jerusalem community in the possession of seven hospices in the West, one of them supposedly in Pisa, but in reality, with one possible exception, no such Western hospice belonged to the Hospital in $1113 .{ }^{13}$ Pisa was a major pilgrim port and it did have various hospices, including in 1126 a hospitalis and a later church which had been built by $1138 ;{ }^{14}$ it was dedicated to the Holy Sepulchre and had an octagonal church on the Holy Sepulchre plan. Presumably this church, like a number of other Western possessions of the Holy Sepulchre, ${ }^{15}$ passed to the Hospitallers; there was a Hospitaller prior hospitalis Pisani in $1173^{16}$ and a male Hospitaller community of San Sepolcro in Pisa by $1181,{ }^{17}$ but a transfer to the Hospitallers could have taken place much earlier. There may have been in Pisa a female house dedicated to Saint John by $1149^{18}$ and such a house evidently existed by the time of Ubaldesca's death in 1205 or 1206; that house was in fact documented as a separate entity only thereafter. ${ }^{19}$ After 1099 the women's hospice in Jerusalem ceased to function as such and the main hospital there subsequently became a flourishing medical institution which cared for both men and women. Later a number of houses for fully-professed Hospitaller women members of the Order were founded in the West, notably at Sigena in Aragon in about 1184, at Buckland in England by about 1185 and, though with only a brief existence, at Prague in about $1180 .{ }^{20}$ That the women's house in the Carraia del Gonella was already a Hospitaller institution by about 1155 when Ubaldesca first went to Pisa seems unlikely.

13 A. Luttrell, The Earliest Hospitallers, in: Montjoie: Studies in Crusade History in Honour of Hans Eberhard Mayer, ed. B. Kedar et al., Aldershot 1997, pp. 37-54; the existence of a Hospitaller hospice in Pisa in 1113 had previously been accepted.

14 Zaccagnini (as n. 1), pp. 110-111; dates in A. Patetta, Gli Ospedali di Pisa: Sanità e Assistenza nei secoli XI-XV , Pisa 2001, pp. 107-109, 136-139; M. L. Ceccarelli Lemut, G. Garzella, Ordini Militari in una Città di Mare: Ospitalieri e Templari nella Pisa medievale, in: Cavalieri e Città, ed. F. Cardini et al., Volterra 2009, pp. 56-57. Amico (as n. 1), p. 17, interprets the 1126 church as a Hospitaller hospice dedicated to the Holy Sepulchre, though that is not what the text stated.

15 Cf. Luttrell, Earliest Hospitallers (as n. 11), pp. 42-44, 47-49.

16 Luttrell, Studies (as n. 8), p. 104.

17 Zaccagnini (as n. 1), p. 111.

18 Amico (as n. 1), pp. 19, 37, 125.

19 Zaccagnini (as n. 1), p 115-116, following G. Garzella, Pisa com'era: topografia e insediamento dall'impianto tardoantica alla città murata del secolo XII, Naples 1990, pp. 117-118, n. 71, which claims that San Giovannino is documented as a Hospitaller house in 1207; Amico (as n. 1), pp. 18-19, disputes that, but the references of 1150 and of 1193 onwards in ibid., pp. 19-21, do not show it as a Hospitaller house.

20 Luttrell, Nicholson (as n. 2), pp. 3-9, 13-15. 
Although she came from a peasant family, Ubaldesca was an early example of a "lay saint" devoted to charitable work in an urban context and she was also one of the first identifiable "holy anorexics". ${ }^{21}$ She was not a professed religiosa of any order and she shared many characteristics with other lay saints who lived in Italian towns of her time and who were technically beate rather than formally canonized sancte; she did not live in clausura. Her recognition was evidently fostered for their own purposes by the Hospitallers to whom she was attached, as the description of her death and burial given in her Vita made clear. The Vita recorded that as Ubaldesca's end became imminent, the Hospitaller priest of the male house of San Sepolcro, Fr. Dotto degli Occhi who was possibly her confessor, told the sisters at nearby San Giovannino that he wished to be present at her death, but Ubaldesca said 'Father, you will not come in time', and indeed she died while he was absent. The abbess and the priest buried her in the church of San Sepolcro with much devotion in the presence of a great crowd. Fr. Dotto prayed by the corpse for seven days until he witnessed Ubaldesca being taken to heaven by angels; after that he had her corpse placed in a new tomb and many miracles followed. ${ }^{22}$

\footnotetext{
21 Ubaldesca is the first in a modern chronological list of 261 identified holy anorexics: R. Bell, Holy Anorexia, Chicago 1985, p. 215.

22 Details in the Vita in Zaccagnini (as n. 1), pp. 224-245; a modern Vita of Fr. Dotto is published ibid., pp. 177-181.
} 